\title{
A Study of the development of Natuna Regency as a key site on Indonesia's Outer Border with particular regard to national defense and security issues in the South China Sea
}

\author{
Fernandes Simangunsong \\ Institut Pemerintahan Dalam Negeri-Kementerian Dalam \\ Negeri, Indonesia \\ fernandes_simangunsong@ipdn.ac.id
}

\author{
Imelda Hutasoit \\ Institut Pemerintahan Dalam Negeri-Kementerian Dalam \\ Negeri, Indonesia \\ imelda77_soit@yahoo.com
}

\section{Publication Information:}

Received 27 September 2018, Accepted 30 November 2017, Available online 31 December 2018

doi: 10.21463/jmic.2018.07.2.04

\section{Abstract}

This study profiles defense and security issues and relevant to the development of Natuna Regency, Riau Islands Province, Indonesia. The area is located close to Indonesia's maritime borders with Malaysia, Singapore, Vietnam and Cambodia and adjacent to a major international shipping route between East Asia and the Indian Ocean. Due to its location, state management of the Regency involves the co-ordination of various components to anticipate threats, including potential military intervention by other countries and other activities such as terrorism, smuggling, illegal drug trading, illegal fishing, etc. The method of study used for this article was exploratory, using interviews, observation, and document study to produce analysis. The result of our findings is that, from a national security point-of-view, military bases in Natuna should be strengthened in acknowledgement of the strategic value of the territory with regard to the defense of Indonesian borders.

Keywords

Natuna, Territorial development, Indonesia's outer border region, South China Sea, strategic defense interests 


\section{Introduction}

Indonesia is the largest archipelagic state in the world and its terrestrial component comprises approximately 17,000 islands. This article concentrates on one particular group, the Natuna Islands, located within the North Natuna Sea (Figure 1). The region has rich natural resources, such as minerals and fish, and is located on a prime international route for ships travelling between the Indian Ocean and East Asia, carrying valuable cargos such as liquefied gas (Figure 2). Internationally, the sea is often considered as a "commons" - i.e. the legacy of all human beings - and, therefore, every country is entitled to exploit its marine resources (outside of national territorial waters). However, this situation requires careful management as conflicts can arise if countries exploit resources without clear understandings of national maritime boundaries and the rights and obligations of each country regarding them, since this issue is closely related to the security and sovereignty of all countries with coastlines and/or fleets (BAPPENAS UNDP, 2008:12).

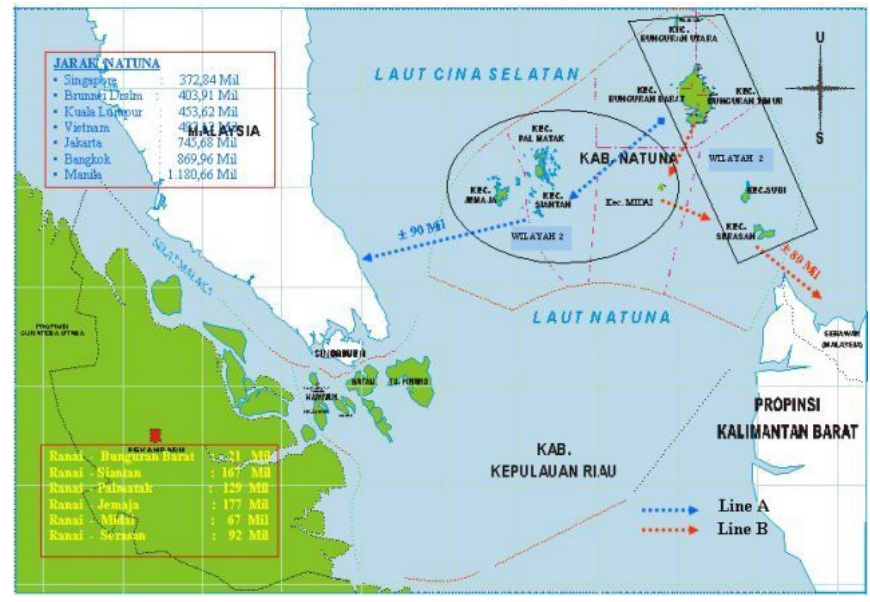

Fig 1. Location of Natuna and adjacent land masses.

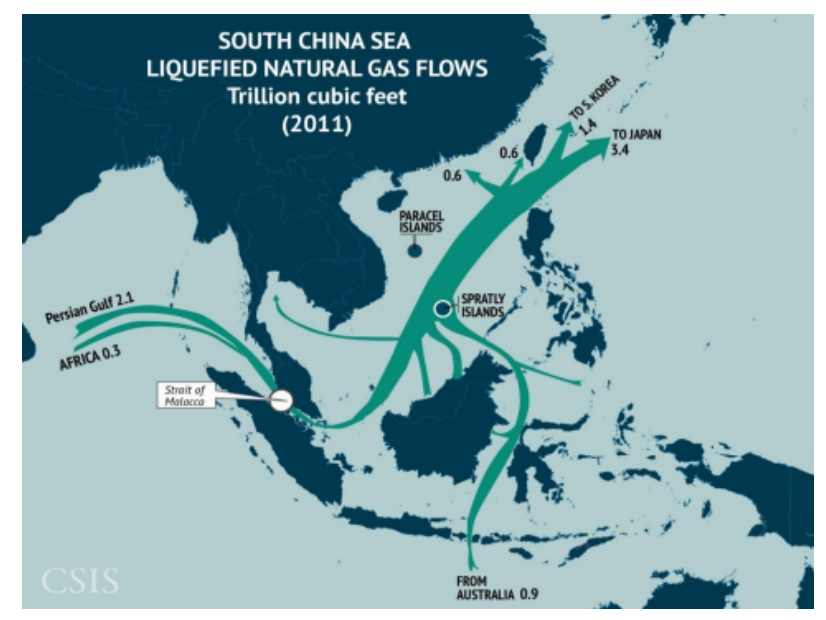

Fig 2. Routes of ships carrying liquefied gas through South China Seas (Source: CSIS, 2017:3) 
The desire for possession of the sea, on the one hand, and the characteristic of the sea as an open space, on the other, have resulted in countries with maritime interests consenting to agreements and international rules that regulate maritime matters but issues concerning these frequently arise, and maritime territories are often subject to disputes involving various countries. For example, Natuna became the subject of such a dispute in 2009 when China included it as part of its national territory in a map that expressed its perception of its maritime border in the South China Sea marked by nine line points, known-and subsequently referred to here-as the 'Nine Dash Line' (NDL) (Figure 3). The size of the area encompassed by the NDL is 3.5 million square kilometers, covering $90 \%$ of the whole South China Sea.

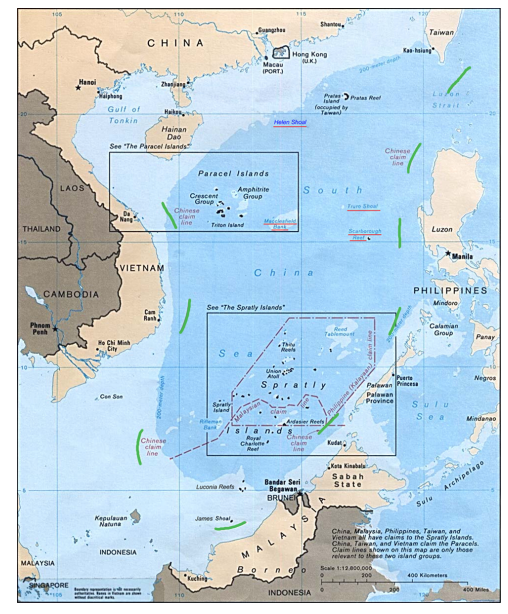

Fig 3. Map of South China Sea showing China's Nine Dash Line Claim (in green): modified version of 1988 map from U.S. Central Intelligence Agency - Asia Maps - Perry-Castañeda Map Collection: Wikimedia Commons

China's claim has had great impact on Indonesia regarding its sovereign territorial rights and its maritime Economic Exclusion Zone (EEZ). Natuna and the wider Pulau Tujuh region thereby have a considerable strategic significance and need to be protected in order to have their economic, political, socio-cultural and defense and security capacities enhanced. Geo-strategically, Indonesia has three principal reasons to increase planning and resourcing of the area:

1. To maintain the integrity of the unitary state of the Republic of Indonesia, to ensure national security and defense, and to create regional stability;

2. To exploit natural resources in a manner that preserves that natural environment; and

3. To empower the regional population to enhance their welfare.

\section{Research Methods}

Addressing those factors detailed above, this study aimed to extensively explore the causes and potential for territorial development in Natuna Regency. The techniques used to collect data were: 
- Interviews with the leaders of the Indonesian Army, Navy, Air Force and National Police who are responsible for the Riau Islands, the Regent of Natuna, the Speaker of the Regional House of Representatives (DPRD), heads of district (Camat), several concerned Local Government Agencies (SKPDs), public figures, religious leaders, educational figures, youth figures, and female leaders in the fifteen districts in Natuna regency.

- Observation of relevant SKPDs, public figures, religious leaders, educational figures, youth figures, and female leaders in the fifteen districts in Natuna regency.

- The study of published material on the national security and defense sector and regional regulations on territorial development in Riau Islands Province and, specifically, Natuna Regency.

\section{Regional Factors and Contexts}

While Natuna is little known outside of Indonesia, it is possible that the regency, centered on the capital of Ranai, will draw more attention in future years. The Natuna Islands have been the outermost northern territorial point of the Republic of Indonesia since the Djuanda Declaration in $1957 .{ }^{1}$ Natuna is important for Indonesia for four main reasons. First, in terms of geography, its territorial waters border Cambodia and Vietnam to the north, Singapore and peninsular Malaysia to the west, and Eastern Malaysia to the east. In addition, Natuna is located on an international shipping route that connects East Asia through to the Indian Ocean. Second, in economic terms, the Natuna Islands have rich natural resources, including natural gas reserves of more than 222 trillion cubic feet that constitute one of the largest sources in Asia. The Natuna D-Alpha block gas field is said to be able to supply the needs of natural gas in Indonesia for 70 years and only 5 out of 16 blocks of natural gas resources have been exploited to date, while the rest are still being explored (Offshore Technology Focus, 2018). Third, the regency is estimated to have potential fishery resources of more than 1 million tons per year, of which only about $34 \%$ has been exploited and with only $4.3 \%$ of its resource being accessed by locally-based operations (Global Review 2015). It is unsurprising, in these regards, that its marine territory has been targeted for fishing by Vietnamese, Chinese, Malaysian and Thai fleets whose excessive trawling has been detrimental to Indonesian fish stocks. Reflecting this, the Jakarta government plans to send thousands of ships to the area in order to build an integrated fish processing industry (Ministry of Marine Affairs and Fisheries, 2016:3). Fourth, with regard to tourism, Natuna regency has the potential to develop as a major centre. In addition to its islands and ample aquatic spaces, the regency is located advantageously close to major Asian centers such as Singapore and Hong Kong and would merit sustained investment from the Ministry of Tourism to accommodate and access these markets.

The factors detailed above demonstrate the region's assets and the potential that can be exploited by the Indonesian government. With regard to these, and to the area's strategic location, the central government has recently moved to increase the number of Indonesian Armed Forces (TNI) present in the area and its primary weaponry defense system (alutsista). As cited in Riausky.com (2016):

- The TNI has built a jet fighter base in Natuna to allow Sukhoi Su-27 units to be maintained on standby in the islands and is constructing a runway of $2.5 \mathrm{kms}$ length near Ranai Airport for the planes.

- TNI has added an infantry battalion from the Military Area Command (Kodam) I of Bukit Barisan to monitor and patrol Natuna. The Indonesian Army is also resolved to add another infantry battalion to protect the area and its rich natural gas reserves. 
- The Western Indonesia Fleet of the Indonesian Navy has relocated tens of ships to the area, resulting in reduced numbers of foreign ships in the region.

In addition to strengthening defenses, the economic, political, and administrative aspects of the Natuna Islands also need to be developed to enhance the strategic assets of the region and to further Indonesia's goal of being a pivotal maritime nation in accordance with the first of President Jokowi's Nawacita (Nine Priorities) declared in 2014, i.e.:

to return the state to its task of protecting all people and providing safety to all citizens through free and active foreign politics, reliable national security and the development of an integrated forces concept for national defense based on national interests and to strengthen national identity as a maritime nation.

These reasons are in accordance with the central government zoning plan for Outermost Small Islands (Pulau-pulau Kecil Terluar - PPKT), i.e. a) defense and security; b) social welfare; and c) preservation of environment. (GR No. 62 of 2010 on Exploitation of PPKT, Natuna Regency Number 2015)

Considering the third of President Jokowi's Nine Priorities, i.e. "to build Indonesia from its peripheries by consolidating regions and villages within the framework of unitary state"; it is necessary to consolidate peripheral regions based on national strategic interests, defense and security and economic aspects. Law No. 23 of 2014 on Local Government, Article 49 clause (1) states that the formation of a region based on national strategic interests - as referred to in Article 31 clause (4) - applies to borderlands, outermost islands, and specific regions to maintain the interests and sovereignty of the unitary state of the Republic of Indonesia.

From an administrative aspect, regional consolidation and rearrangement can involve the creation of new regions, the merging of regions, the resetting of borders and/or the development of a special region according to its potential. Regional rearrangement is considered in order to address the challenges of change and to fulfil public demands for provision of basic needs such as education and health. Organization is expected to be able to adapt to planned changes so that it can ensure optimization and effectiveness in implementation of administrative functions. Wasistiono (2002:11) has posited the purposes of establishing a local government organization as (1) to serve public interests, conceived in terms of customers and stakeholders, and (2) to pursue objectives rather than merely to implement laws and regulations.

Modifications to the extent and scale of a province (or other entity, such as regency/city, district, sub-district and village) that reduce their sizes have implications for the degree of control exercised by leaders of relevant organizations. The scope of control by organizational apparatuses becomes more restricted, giving them more opportunities to monitor, assess and control human resources and natural resources. It should be noted in this context that that public service is not merely an administrative activity. Success in administration and government and development requires public participation. Success in regional rearrangement also requires support from the public as well as social control over it. In relation with this, Wasistiono (2009:13) suggests that the:

Creation of new region or, more precisely, dividing an autonomous region into several regions, aims to bring services closer to the public and to optimize the public service, to accelerate growth and development for better public welfare in the region. Public participation will increase if there is more open access and more effective control due to relatively narrower area of control.

A "slim" organizational structure is also important for coordination, according to the principle of "slim structure, rich functionality." The advantages of having a slim organizational structure are, inter alia: 
1. improved public service due to shorter procedures and quicker decision making;

2. improved communication between levels of management; and

3. improved coordination.

In accordance with this, the main dimensions that affect the effectiveness of regional rearrangement are control, communication, and coordination, all of which determine the level of public service. The further the population is from an administrative center, the smaller its opportunity to be provided with service. Increased demands for services require administrative centers to expand their services. However, administrative centers have limited radiuses of service, and therefore additional service centers are needed to meet public needs for service. Through regional rearrangement, the number of administrative centers can be increased, allowing them access to settlement areas that were previously remote from them, with government services being more evenly distributed, thereby improving public welfare (Nasution, 2000).

Natuna Regency was established as a result of regional rearrangements instituted in 1999 by Law No. 53, which divided the Riau Islands Regency. The Natuna Regency has developed significantly since its creation and now has 15 districts covering an area of 2,009.04 square kilometers, most which is sea. In addition to its strategic location, the Regency is rich in natural resources that have not been managed properly, i.e.: Sea fishery resources of more than 1 million ton per year with total exploitation of only $36 \%$ and only $4.3 \%$ for Natuna Regency; agriculture and plantation such as root crops, coconut, rubber, palm oil and cloves; tourism objects: marine (beach, diving), mountains, waterfalls, caves, and cultivation; D-Alpha gas field, located $225 \mathrm{~km}$ north of Natuna Island (within Indonesia's IEEZ), with a total reserve of 222 trillion cubic feet (TCT) and hydrocarbon gas of 46 TCT (making it one of the largest in Asia). Its strategic location, both geopolitically and geo-strategically, and relative unexploited potential natural resources, are reasons to develop this territory into several regions, such as Ranai city, West Natuna Regency and South Natuna Regency, and, in the future, informed by proper research and planning, may be developed into a new province.

19 of the 2,408 islands in Riau Islands Province are outermost ones that directly border the territorial waters of Singapore, Malaysia, Cambodia, and Vietnam. 7 of the 19 are not populated: Kepala, Semiun, Sebetul, Sekatung, Senua, Subi Kecil and Tokong Boro. As the outermost small islands are borderlands, they face various threats - both military, such as intervention from other countries, and non-military, such as terrorism, smuggling, illegal drug trading and illegal fishing. In order to prevent external intervention, the Indonesian Army, Navy, and Air Force has strengthened its defense of Natuna over the last five years, including the deployment of 800 soldiers and an increase in overall personnel to 2,000 since 2016. The Indonesian Air Force also plans to increase the number of jet fighters based in the territory despite Natuna currently lacking facilities to adequately service these. (Ministry of Defense of the Republic of Indonesia, 2017:12)

To facilitate national defense within geopolitical and geostrategic perspectives, an Office Memo from the Director General of Defense Strategy in the Ministry of Defense provided input into the spatial planning of Natuna Regency and the establishment of military installations by asserting that:

- The draft Presidential Regulation on Spatial Planning for National Borderlands in Riau Province and Riau Islands Provinces has identified Ranai (the capital of Natuna regency) as a national strategic activity center.

- Regional Regulation No. 10 of 2012 on the Spatial Planning of Natuna Regency includes provision of territory for national security and defense in article 42, and location plans for infantry battalion (Yonif) 135/Raider at Sepempang Village and Sungai Ulu Village, East Bunguran District, in designated settlement areas. 
- Government Regulation No. 68 of 2014 on Defense Territorial Plan article 26 clause (1) states that the national and/or local government should prepare land for establishment and development of defense territory (as stated in article 6 points $\mathrm{a}-\mathrm{g})$.

- From a regulatory aspect, the establishment of Yonif 135/Raider at Sepempang and Sungai Ulu villages in designated settlement areas does not contravene regional regulation No. 10 of 2012 on Spatial Plan for Natuna Regency.

- Coordination between the Regional Development Planning Agency (Bappeda) of Natuna regency and Military District Command (Kodim) 0318/Natuna resulted in the location assignment of Yonif 135/Raider.

Consideration of the preparation of land for the establishment and development of defense territory is an obligation of local government and the location of Yonif 135/Raider's base is in thereby in accordance with its designation as a defense territory in Natuna Regency's spatial plan. To secure the planning for development of various military installation areas in the island, Paragraph 8 of Other Designated Areas of Article 42 of Natuna's Spatial Plan has the following provision:

1. Other designated areas as stated in Article 34 point $\mathrm{i}$ include:

a. National Security and Defense Areas;

b. Administrative Center Areas;

c. Great Mosque Areas; and

d. Coastal Reclamation Areas.

2. The national security and defense area mentioned in clause (1) will cover 660 hectares, comprising:

a. The Army Installation Area in East Bunguran;

b. The Naval Installation Area (consisting of Pulau Tiga, Pulau Laut, Pulausubi, Pulau Serasan, Pulau Sabang Mawang, and Pulau Midai);

c. The Air Force Installation Area in East Bunguran; and

d. The Combat Training Zone in Tanjung Sengiap.

President Joko Widodo plans to position Indonesia as global maritime pivot, informed by a policy that will attempts to manage disputes between countries over the North Natuna Sea through international reconciliation. However, in the past few months, Indonesia has also significantly strengthened its military presence in Natuna in response to perceived increased levels of Chinese assertion in the region. While Indonesian officials have criticized China in the past due to its claim on Indonesia's EEZ around Natuna, current national policy is essentially neutral with regards to China after the latter's recent declaration of "no objection" regarding Indonesia's sovereignty over Natuna. However, the Minister of Defense of Indonesia, (Retired) General Ryamirzad Ryacudu, has identified that while the situation has been better in the past few months: "We have strengthened our military capacity to anticipate various threats, of either illegal fishing or illegal intrusion into Indonesia territory," (Ministry of Defense of the Republic of Indonesia, 2017:15). The Minister of Defense has also stated that while it has cost Rp196 billion (approximately US\$14.2 million) to strengthen its military base in Natuna there is no anticipation of increasing conflict in North Natuna Sea and the Government prefers to conceive its actions as "defense diplomacy". The strategic importance of the South China Sea trade route, which moves international goods and services worth over US\$5 trillion (Defense Ministry of The Republic of Indonesia, 2015) has exacerbated tensions in the region, with China and the United States contesting each other's rights to operate in and transit through the region. China has also been involved in building up reefs to form terrestrial bases over the last two 
years at an unprecedented rate. In relation to these tensions, President Joko Widodo has asserted that Indonesia will remain as a "truthful mediator" in this dispute, and it has "no reason" to get engaged in it.

\section{Analysis and Discussion}

The Asia-Pacific region is strategically important in economic, political and military terms given that it includes nations with populations of more than one billion (India and China) and a variety of nations with modern military technology and considerable military personnel resources. From traditional security perspectives, the Asia-Pacific region has potential flashpoints that may cause international conflict (Figure 4). As a result, disputes in the South China Seas and around the Korean Peninsula, and other conflicts in several border regions, need to be responded to wisely. Regarding potential threats in the region, China has caused particular concern by establishing permanent buildings on Scarborough Shoal, located close to The Philippines, and infrastructures on Fiery Cross Reef in the Spratly Islands. China has also claimed sovereignty on all islands, reefs and waters within their unilaterally declared NDL. The threat is now an actual rather than theoretical one. For example, recently there have been incidents of Chinese fishing ships escorted by Chinese coastal patrol boats working within Indonesia's EEZ near Natuna Island, such as fishing boat Gui Bei Yu 27088, which was detained close to Natuna. The presence of escort boats is significant because it confirms China's perception of these waters as its own. Meanwhile, with regard to non-traditional security, the region has a long history of smuggling (involving drugs, humans and weapons, in particular), sea piracy, theft of natural resources and separatism. Over the past three decades, concern over terrorism has also increased due to economic factors and radicalism.

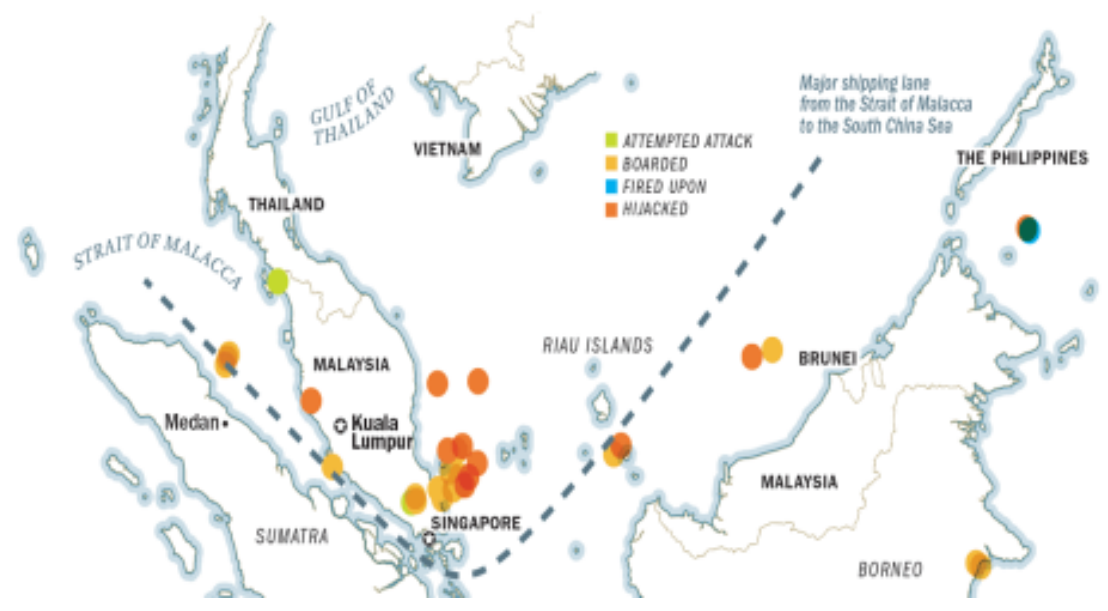

Fig 4. The strategic position of the Riau Islands with regard to the main shipping route through the region (and indication of conflict incident points)

Disputes concerning the North Natuna Sea could potentially flare into open armed conflict due to three reasons. 1) parties engaged in such disputes frequently use military instruments to pursue their claims. 2) there are countries 
outside the area involved in the disputes. 3) there is no credible international institution or organization able to resolve the disputes.

Indonesia conceives its national defense system as universal, involving all citizens, regions, and other national resources, and the system is implemented in total, integrated, directed, and continuous manners to maintain and protect national territorial integrity, national sovereignty and security. Article 12 of Law No. 3 of 2002 on National Defense identifies that, "Management of the national defense system as one of the functions of government aimed to protect national interests and support national policy in the sector of defense". And Article 13 clause (1) also states that, "The President is authorized and responsible in the management of the national defense system". The main component in the implementation of national defense is the Indonesian Armed Force (TNI), and other components within the scope of national defense system are society and national resources that can be utilized for national defense.

According to Van Evera (1998), there are several factors that influence the state in policy-making relating to its defensive force - including military, geographical, socio-political and diplomatic ones. These four factors directly influence defense policy formulated by a country, and the defensive force of a country will always reflect these four factors. In Indonesia's New Order Era (1966-1998) national policies focused on developing land defense forces, neglecting the nature of the country as an agglomeration of islands and marine spaces.

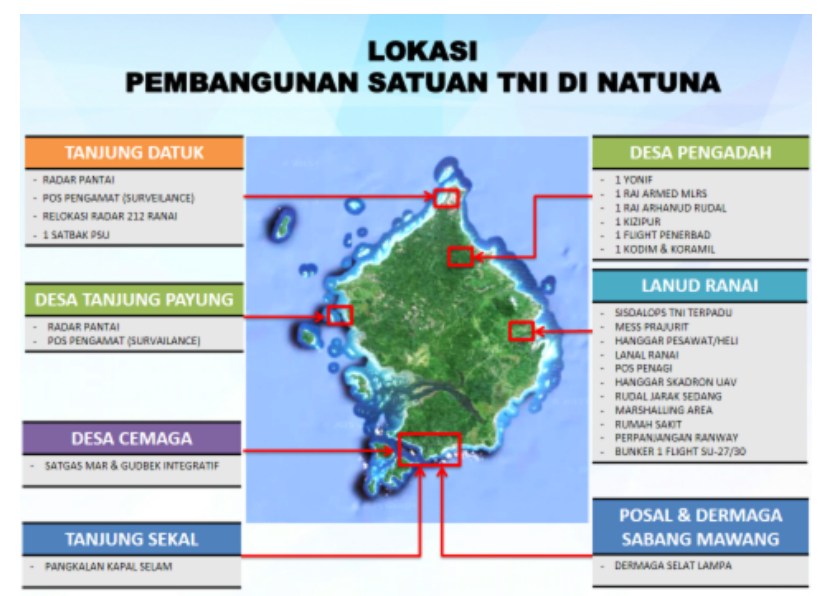

Fig 5. Location of military units in Natuna (Source: TNI Headquarters, 2017)

The establishment of a military base in Natuna is a key development for security in the region and is beneficial for public welfare with regard to property and human security. These aspects are particularly appropriate given the underdevelopment of many of Indonesia's borderlands. The third point of Nawacita identifies the importance of developing borderlands, stating its intention to "to build Indonesia from its peripheries by consolidating regions and villages within the framework of a unitary state."

There are five strategic issues that need to be considered when developing borderlands:

1. The establishment of identifiable borderlines in several regions and/or in areas that are disputed with neighboring countries. Uncertainty over such issues impedes development. 
2. Illegal activities undertaken in uncertain border regions.

3. The provision of health, education, and other services, which are pressing issues in borderlands that often have low population densities and widely dispersed population centers.

4. Infrastructural problems that impede access to border regions.

5. Institutional factors.

Potential threats towards sovereignty require the state to be present through initiatives such as the development of military facilities, including coastal radar and surveillance systems, and the establishment of various army, navy and air force units and the facilities to accommodate and service their personnel in designated national defense areas. TNI's policy of developing the Natuna Islands through establishing military base facilities is enhanced by synergy with the civilian government Research by LIPI (2007:13) suggests that one factor that influences defense is population size. Citizens are, indeed, in the vanguard of defending national security. Awareness of conventional and non-conventional threats can be the greatest stimuli to make all parties share a common mindset and attitude to unite and to strive to defend their homeland together.

\section{Conclusion}

Based on the analyses and discussion advanced in this article, it can be concluded, from an Indonesian perspective, that:

1. In relation to the geostrategic and geopolitical situation of Indonesia in the South China Sea, the development of the Natuna Islands needs to (simultaneously and holistically) incorporate both social welfare and security and defense concerns.

2. There are serious potential threats to the Natuna Island area, such as smuggling, illegal fishing and logging, terrorism, territorial claims, and the possibility of open warfare between disputing countries.

3. (Following on from the above) the military base in Natuna should be strengthened in order to monitor strategic maritime routes, to defend Indonesian borders and to monitor potential hostilities developments between other nations in the region.

4. The seven outermost islands in Natuna regency are vulnerable to occupation because they are unpopulated. It is therefore particularly important to have a continuing human and military presence on them.

\section{Endnotes}

1. The Djuanda Declaration defined Indonesia's national territory as an area that encompassed both its multiple islands and all the marine areas bounded by its outer limits. 


\section{References}

BAPPENAS., UNDP, 2008. Study of Evaluation of the Impact of Regional Division 2001-2007. National Development Planning Agency of the Republic of Indonesia. Jakarta.

BAPPENAS., UNDP, 2016. Study of Evaluation of the Impact of Regional Division 2009-2015. National Development Planning Agency of the Republic of Indonesia, Jakarta.

CSIS., 2017. 3 Tahun Jokowi: kenaikan electoral \& kepuasan public.

https://www.csis.or.id/uploaded_file/event/pemaparan_hasil_survei_opini_publik_tiga_tahun_pemerintahan_joko_widodo__jusuf_kalla_kinerj

a_pemerintahan_dan_peta_politik_nasional_notulen.pdf.

Global Review, 2015. National interest: pangkalan militer Natuna. http://theglobal-review.com/lama/content_detail.php? lang=en\&id=16958\&type=108\#.W_0XyWayTIV (in Bahasa).

Indonesian Central Bureau of Statistics., 2015. Natuna Regency in Numbers 2015.

Indonesian Government Ministry of Defense, 2017.

Indonesian Government Ministry of Defense, 2015. The Dynamic of strategic security environment in the Asia Pacific region.

Indonesian Government Ministry of Home Affairs., 1999. Local Government Law No. 22.

Indonesian Government Ministry of Home Affairs., 2014. Formation of Region Based on National Strategic Interests, Law No. 23 of 2014 on Local Government. Ministry of Home Affairs, Jakarta-Indonesia.

LIPI (2007)

Nasution, A.B., Mallarangeng, A.A., Amal, I., et al 2000. Federalism for Indonesia. PT. Kompas Media Nusantara, Jakarta.

Offshore Technology Focus, 2019. Natural Gas Field - Greater Sarawak Basin. https://www.offshore-

technology.com/projects/natuna/natuna1

Riausky.com (2016/4/1). https://riausky.com/

Simangunsong, F. 2014. Division Regional Post-Birth of Law Number 23 Year 2014 about Local Government, Lecture Papers for Graduate School (Masters and Doctorate) at Governmental Institute of Home Affairs. Governmental Institute of Home Affairs, Bandung. (Not Published).

Van Evera, Stephen, 1998. Offense, defense, and the causes of war. International Security. 22:5-43.

Wasistiono, S., 2002. Reorganized District Government Institutions, Government Study Center STPDN. PT Citra Pindo, Bandung.

Wasistiono, S., Nurdin, I., Fahrurozi, M., 2009. Development of the District Organization from Time to Time, Institute of Local Government Management Studies. Fokusmedia Publishers, Bandung. 